Click www.researchjournal.co.in/online/subdetail.html to purchase.

INTERNATIONAL JOURNAL OF PLANT PROTECTION

\title{
Evaluation of technological gap and performance of low yield of tomato due to fruit borer
}

\author{
Laxman Prasad Balai ${ }^{1 *}$, Dheeraj Singh ${ }^{2}$ and M. L. Meena ${ }^{2}$ \\ ${ }^{1}$ Krishi Vigyan Kendra (SKNAU, Jobner), Dholpur (Rajasthan) India \\ ${ }^{2}$ ICAR-Centre Arid Zone Research Institute, Krishi Vigyan Kendra, Pali (Rajasthan) India
}

\section{ARITCLE INFO}

Received : 29.07 .2020

Revised : 07.09 .2020

Accepted : 22.09.2020

\section{KEY WORDS :}

H. armigera, Tomato, Yield losses, Extension gap, Technology gap, Technology index, OFT, B: C ratio
*Corresponding author:

Email : laxmanbhu08@gmail.com

\begin{abstract}
The experiment was carried out to evaluation of technological gap and performance of integrated pest management (IPM) come upto as a resistant variety, tap crop as marigold line, bio pesticides as Ha NPV, chemical spray as sucking pest Dimethoate at before flowering time and borer managemant as Acephate fruiting time of tomato fruit borer, Helicoverpa armigera pest under field condition. This experiment was conducted on farmer trials (OFT) at different villages likewise Hemawas, Sandeyo Ki Dhani and Baldo Ki Dhani in Pali district (Rajasthan) during period of three year (2015 to 2017). During this experiment pest infestation of fruit borer was observed to be lowest (Pest infestation $12.0 \%$ ) when, resistant variety Heemsohna, tap crop use African marigold, tomato line ratio 2:14, Ha NPV 250 LE @ $0.4 \mathrm{ml} /$ lit of water at 30 DAP and 45 DAP Dimethoate $0.5 \mathrm{ml} /$ lit at before flowering time and Acephate $0.5 \mathrm{~g} /$ lit at 45 fruiting time. Maximum infestation pest damage $(44.00 \%)$ was observed when traditional farmers practice (FP). The adoption of recommended improved tomato production technology and plant protection measures was poor. The main objective of the OFT was to conduct extent of technological gap between recommended and actually adopted tomato technologies by the tomato growers from Pali district. It is suggest organising result OFT and field visits for minimizing technological gap by agriculture department. The OFT was effective in changing attitude, skill and knowledge of IPM approach and tomato fruit yield increased upto 57.52 per cent more over the traditional FP. Results indicates that IPM approach increased net income by Rs. 1,74,781/-ha over FP.
\end{abstract}

How to view point the article : Balai, Laxman Prasad, Singh, Dheeraj and Meena, M.L. (2020). Evaluation of technological gap and performance of low yield of tomato due to fruit borer. Internat. J. Plant Protec., 13(2) : 166-170, DOI : 10.15740/HAS/IJPP/13.2/166-170, Copyright@ 2020: Hind Agri-Horticultural Society. 